\title{
Pembangunan Daftar Kata Terkait pada Kosa Kata Al-Qur'an Berdasarkan Kesamaan Distribusional
}

\author{
Fedy Fahron Guntara*1, Moch. Arif Bijaksana ${ }^{2}$, Arief Fatchul Huda ${ }^{3}$ \\ ${ }^{1,2}$ Universitas Telkom; Jl. Telekomunikasi no. 1, Terusan Buah Batu, Bandung, (022) 7565930 \\ ${ }^{3}$ UIN Sunan Gunung Djati; Jl. A. H. Nasution No. 105, Cipadung, Bandung, (022) 7800525 \\ ${ }^{1,2}$ Program Studi Informatika, Bandung \\ ${ }^{3}$ Fakultas Sains dan Teknologi, Bandung \\ e-mail: *11 fedyfahron@student.telkomuniversity.ac.id, ${ }^{2}$ arifbijaksana@ telkomuniversity.ac.id, \\ ${ }^{3}$ afh@uinsgd.ac.id
}

\begin{abstract}
Abstrak
Al-Qur'an adalah kitab suci umat Islam yang mengandung banyak kata di dalamnya. Hal tersebut membuat orang awam kesulitan untuk menemukan keterkaitan antar kata yang ada di dalam Al-Qur'an . Contohnya seperti kata مَنَرُروف (perbuatan baik) yang memiliki keterkaitan dengan kata Lَ (memaafkan) karena dalam Al-Qur'an kedua kata tersebut memiliki keterkaitan dalam makna yaitu memaafkan adalah salah satu perbuatan baik. Saat ini masih jarang ditemui kamus, ensiklopedia atau tesaurus kosa kata Al-Qur'an yang menjelaskan tentang keterkaitan antar kata dalam Al-Qur'an . Penelitian ini membahas tentang keterkaitan antar kata dalam AlQur'an dan kedepannya diharapkan dapat membantu dalam mencari keterkaitan antar ayat. Metode yang digunakan pada penelitian ini adalah metode dengan pendekatan kesamaan distribusional berbasis vektor Continuous Bag of Word (CBOW). Penggunaan metode CBOW menghasilkan nilai precision sebesar $98 \%$ berdasarkan dari hasil keluaran sistem dengan koreksi dari ahli bahasa.
\end{abstract}

Kata kunci- Al-Qur'an, cosine-similarity, word2vec, CBOW, precision

The Quran is the Muslim holy book that contains many words in it. This makes it difficult for ordinary people to find connections between words in the Quran. For examples like the word مَعُروف (good deeds) which have a connection with the word (forgive) because in the Quran both words have a connection in the words of forgiveness is one of the good deeds. At present, there are still rarely found dictionaries, encyclopedias or thesaurus of the Quran vocabulary that explain the interrelationships of words in the Quran. This study discusses the interrelationship of words in the Quran and the future is expected to help in finding the interrelations between verses. The method used in this study is a method with a distributionbased equality approach based on Continuous Bag of Word (CBOW). The use of the CBOW method produces a precision value of $98 \%$ based on the results of the system output with the correction from linguists

Keywords - Quran, cosine-similarity, word2vec, CBOW, precision 


\section{PENDAHULUAN}

Al-Qur'an adalah salah satu kitab suci atau buku umat Islam yang menjadi petunjuk setiap manusia. Sekitar $24 \%$ daripada populasi masyarakat dunia yang merupakan uamt Islam [1] membaca dan mempelajari tentang Al-Qur'an yang di dalamnya terdapat banyak pengetahuan atau informasi yang tersembunyi.

Al-Qur'an memiliki 30 juz, 114 surat dan lebih dari 6000 ayat yang terkandung di dalamnya [2]. Dari isi Al-Qur'an yang begitu banyak, membuat orang awam kesulitan untuk menemukan dan mempelajari tentang keterkaitan antar kata yang ada di dalam Al-Qur'an . Permasalahan tersebut dapat diatasi dengan adanya sebuah kamus, ensiklopedia atau tesaurus kosa kata Al-Qur'an dan sebagai salah satu kelengkapannya yaitu tiap entri kata memiliki keterkaitan dengan kata lain. Penelitian ini membahas tentang keterkaitan antar kata dalam AlQur'an dan untuk lebih lanjut diharapkan dapat membantu dalam mencari kemiripan antar ayat Al-Qur'an . Seperti contoh berikut ini: kata مَنْرُوف (perbuatan baik) yang memiliki keterkaitan dengan kata salah satu perbuatan baik adalah memaafkan.

Keterkaitan dan kesamaan semantik berkaitan dengan bidang linguistik khususnya pada Natural Language Processsing (NLP) yang belakangan ini menjadi topik yang menarik dan banyak diteliti. Kesamaan semantik dan keterkaitan kata memiliki peran penting dalam beberapa task dari NLP dan beberapa bidang terkait seperti text classification, document clustering, text summarization, dan lain sebagainya [3]. Pada penelitian sebelumnya yang serupa hanya dilakukan analisis pada pencarian kata-kata yang mengandung atau menginterpretasikan manusia [4], kesamaan semantik antar teks terjemahan Inggrisnya [5]. Pada penelitian tersebut tidak terdapat penjelasan lebih mengenai keterkaitan antar kata dalam Al-Qur'an.

Melengkapi penelitian sebelumnya, maka penelitian ini menganalisis ke level keterkaitan antar kata dalam Al-Qur'an. Pembangunan sistem ini membutuhkan beberapa data seperti lema yang ada di dalam Al-Qur'an. Terdapat berbagai metode yang dapat digunakan untuk menganalisis keterkaitan antar kata. Salah satunya adalah menggunakan pendekatan kesamaan distribusional berbasis vektor, karena setiap kata memiliki ketergantungan terhadap jarak atau sudut yang dibangun antara vektor kata tersebut untuk dapat menghasilkan evaluasi kualitas representasi kata yang tinggi. Faktor tersebut yang menjadi alasan pengambilan basis vektor sebagai metode untuk mencari atau menghitung keterkaitan antar kata dalam Al-Qur'an. Keterkaitan antar kata tersebut dapat diketahui dari perhitungan nilai perbedaan sudut vektor kata-kata tersebut dengan menggunakan cosine-similarity. Sistem yang dibangun diharapkan dapat menghasilkan performansi yang baik berdasarkan nilai korelasi yang dihitung. Nilai korelasi yang dimaksud adalah nilai korelasi yang didapat dari perhitungan precision setelah dikoreksi oleh ahli bahasa.

\section{METODE PENELITIAN}

\subsection{Gambaran Umum Sistem}

Sistem yang dibangun bertujuan untuk menghasilkan himpunan kata yang memiliki keterkaitan dengan kata inputan melalui perhitungan cosine-similarity antara vektor kata yang didapatkan dari word2vec. Gambaran umum dari sistem yang akan dibangun dalam penelitian ini dapat dilihat pada Gambar 1. Pada Gambar 1 tersebut memvisualisasi tahapan-tahapan dalam penelitian ini mulai dari persiapan data, pembuatan model hingga evaluasi performansi. 


\subsection{Dataset}

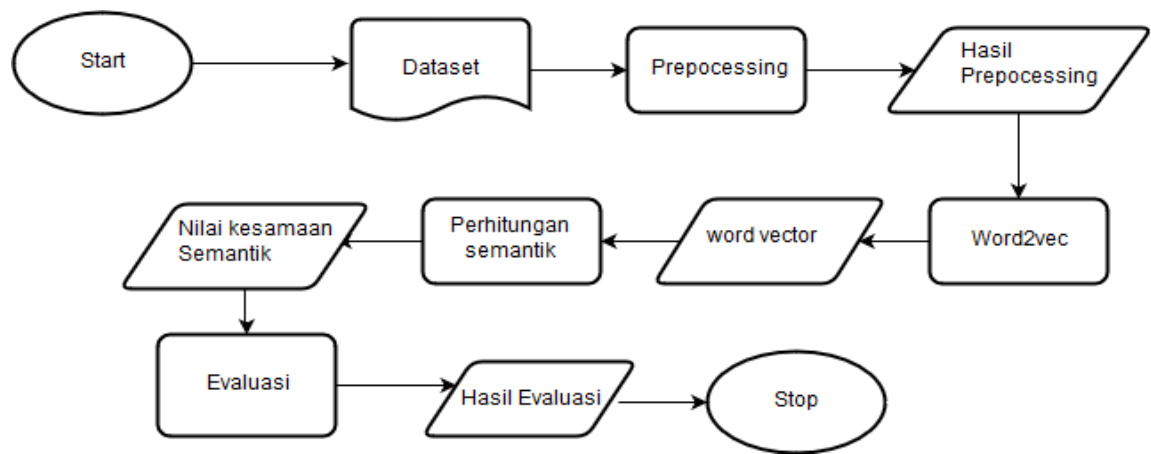

Gambar 1. Gambaran Umum Sistem

Dataset adalah sekumpulan data yang sudah diverifikasi kebenarannya dan dapat digunakan dalam penelitian sebagai sumber data yang valid. Dataset yang digunakan pada penelitian ini didapat dari situs online yaitu corpus.quran.com yang berisikan kumpulan lema yang terdapat pada Al-Qur'an . Kumpulan lema yang terdapat dalam dataset tersebut masih dalam bentuk kode Buckwalter sehingga perlu untuk diproses lebih lanjut.

\subsection{Preprocessing}

Pada tahap preprocessing ini terdapat beberapa hal yang dilakukan diantaranya:

1. Pengambilan kata yang mempunyai lema

Dataset yang digunakan masih terdapat beberapa kata yang tidak mempunyai lema sehingga perlu untuk dihilangkan.

2. Mengubah Buckwalter menjadi arab

Dataset yang dipakai adalah dataset yang mengandung keseluruhan lema yang ada dalam Al-Qur'an dalam bentuk kode Buckwalter sehingga perlu untuk dilakukan encode dari Buckwalter ke arab.

3. Menyatukan lema berdasarkan ayatnya

Proses ini melakukan penyatuan lema berdasarkan posisi ayatnya. Penyatuan lema ini digunakan pada saat proses ke dalam model word2vec sehingga dapat mengetahui setiap konteks dari lema tersebut dalam ayat.

4. Tokenisasi

Ayat-ayat tersebut kemudian dilakukan tokenisasi sebelum diproses ke dalam model word2vec tokenisasi yang digunakan berdasarkan dari spasi.

\subsection{Word2vec}

Word2vec adalah model yang digunakan untuk pemetaan kata menjadi vektor yang dibangun oleh Mikolov dari Google. Pada proses ini akan dilakukan perubahan kata-kata tersebut ke dalam vektor menggunakan metode word2vec tersebut, dengan tujuan untuk mencari kedekatan antar vektor yang satu dengan vektor yang lain untuk menemukan keterkaitan dan kedekatan dari kata tersebut. Metode yang digunakan adalah dengan memanfaatkan metode Continuous Bag of Word (CBOW). CBOW merupakan salah satu teknik dari word2vec yang menganalisa proyeksi vektor untuk memprediksi kata target berdasarkan dari konteksnya [6]. Untuk arsitektur dari metode CBOW sendiri dapat dilihat pada Gambar 2. 


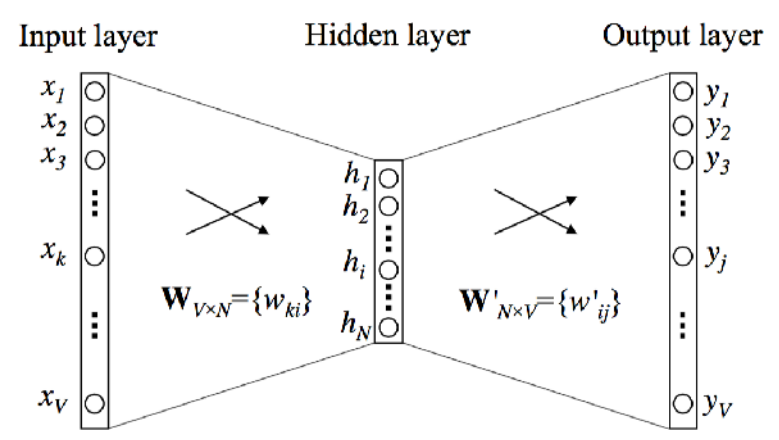

Gambar 2. Arsitektur CBOW [7]

Adapun urutan proses dari word2vec dapat dilihat pada Gambar 3.

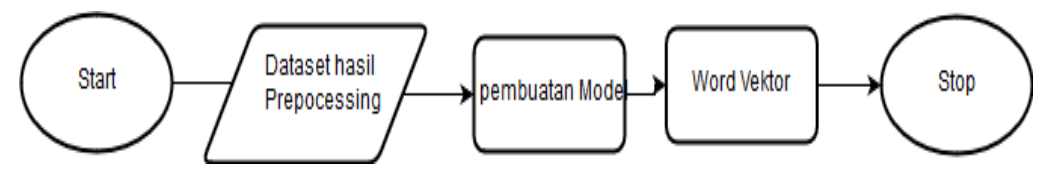

Gambar 3. Word2vec

1. Data hasil dari proses preprocessing akan dignakan untuk proses pembentukan model dari word2vec.

2. Membangun konteks pasangan kata dari data korpus dengan berdasarkan jumlah window size, minimum frekuensi kata, workers $=8$, alpha $=0.22$. Windows size yang digunakan pada penelitian ini sebesar 5 dikarenakan pada penelitian sejenis dengan windows size 5 mengasilkan hasil yang optimal, minimum frekuensi kata yang digunakan sebesar 15 karena untuk mendapatkan lema-lema yang memiliki keterkaitan tinggi.

3. Setelah proses pembuatan model word2vec selesai, maka sistem menghasilkan vektorvektor yang merepresentasikan lema dari dataset.

\subsection{Perhitungan Keterkaitan dan Performansi}

\subsubsection{Perhitungan Keterkaitan Kata}

Ketika kata direpresentasikan sebagai vektor istilah, kesamaan dua kata sesuai dengan korelasi antara vektor. Ini dikuantifikasi sebagai kosinus dari sudut antara vektor, yang disebut cosine-similarity. Cosine-similarity adalah salah satu perhitungan kedekatan vektor paling populer yang diterapkan pada dokumen teks, seperti dalam berbagai aplikasi pencarian informasi [8] dan pengelompokan juga [9].

Setelah melakukan perubahan kata-kata menjadi vektor dengan word2vec selanjutnya akan dihitung kedekatan antar kata-kata tersebut menggunakan rumus cosine-similarity [10] pada Persamaan 1.

$$
\operatorname{Sim}=\cos (\Theta)=\frac{\vec{A} \cdot \vec{B}}{|\vec{A}| x|\vec{B}|}
$$

\subsubsection{Perhitungan Performansi}

Setelah mendapatkan hasil kedekatan dari perhitungan cosine-similarity yang kemudian akan dilakukan perhitungan performansi dengan menghitung nilai precision hasil keluaran dari sistem dengan melakukan koreksi langsung ke ahli bahasa. Precision adalah rasio jumlah dokumen relevan yang ditemukan dengan total jumlah dokumen yang ditemukan oleh sistem [8]. Penggunaan precision pada penelitian ini untuk mengetahui tingkat ketepatan antara

Guntara, et,al [Pembangunan Daftar Kata Terkait pada Kosa Kata Al-Qur'an Berdasarkan Kesamaan Distribusional] 
informasi yang sebenarnya dengan jawaban yang diberikan oleh sistem. Untuk menginterpretasikan angka precision, ditetapkan lima kategori atau kelas yaitu: presisi sangat tidak akurat, tidak akurat, cukup akurat, akurat dan sangat akurat. Sedangkan kriteria atau tolak ukur yang digunakan untuk menyatakan kategori tersebut ialah skala interval, dengan mencari selisih kemungkinan angka precision sangat akurat (1) dengan kemungkinan angka precision sangat tidak akurat (0) kemudian dibagi 5 sesuai kategori penilaian, riilnya adalah $(1-0): 5=$ 0,20 . Dengan demikian kelas interval dari kelima kategori interpretasi precision tersebut dapat dilihat pada Tabel 1.

Tabel 1. Kategori Precision

\begin{tabular}{|c|c|}
\hline Persentase $(\%)$ & Keterangan \\
\hline $0-20$ & $\begin{array}{c}\text { Sangat tidak } \\
\text { akurat }\end{array}$ \\
\hline $21-40$ & Tidak akurat \\
\hline $41-60$ & Cukup akurat \\
\hline $61-80$ & Akurat \\
\hline $81-100$ & Sangat akurat \\
\hline
\end{tabular}

\section{HASIL DAN PEMBAHASAN}

Hasil dari penelitian ini adalah himpunan kata yang memiliki keterkaitan satu sama lain berdasarkan hasil perhitungan cosine-similarity antara vektor kata tersebut. Pada Gambar 4 terdapat visualisasi dari kata-kata yang terdapat didalam Al-Qur'an yang telah direpresentasikan menjadi 2 dimensi. Titik-titik yang terdapat pada Gambar 4 mewakili lema yang ada dalam AlQur'an berdasarkan dari nilai vektor yang dihasilkan dari proses word2vec dan untuk lingkaran yang terdapat pada Gambar 4 menggambarkan kumpulan kata yang mungkin memiliki keterkaitan. 


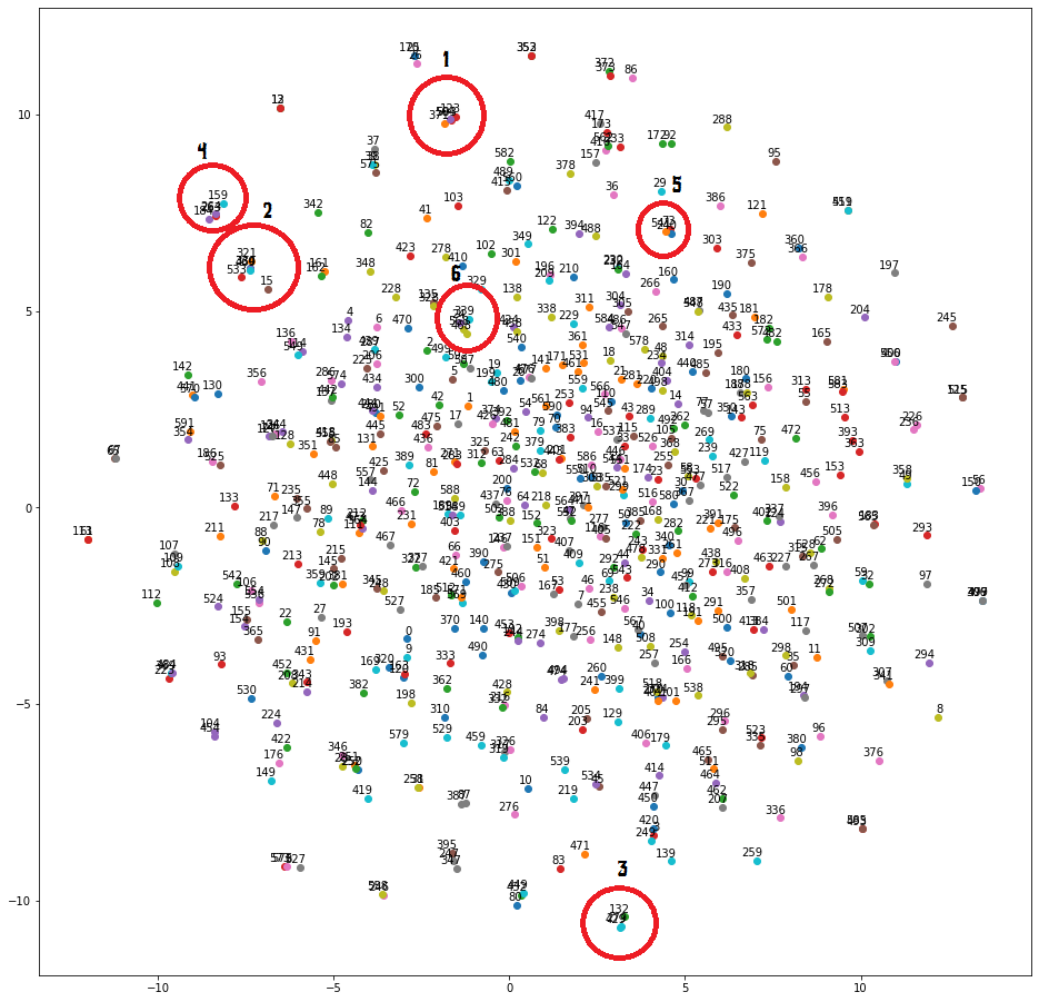

Gambar 4. Visualisasi Vektor Kata

Contoh hasil dari keluaran sistem dengan masukan kata مَّْْرُوف dapat dilihat pada Gambar 5. Sistem akan mengeluarkan 10 kata yang memiliki nilai keterkaitan tinggi dengan kata masukan.

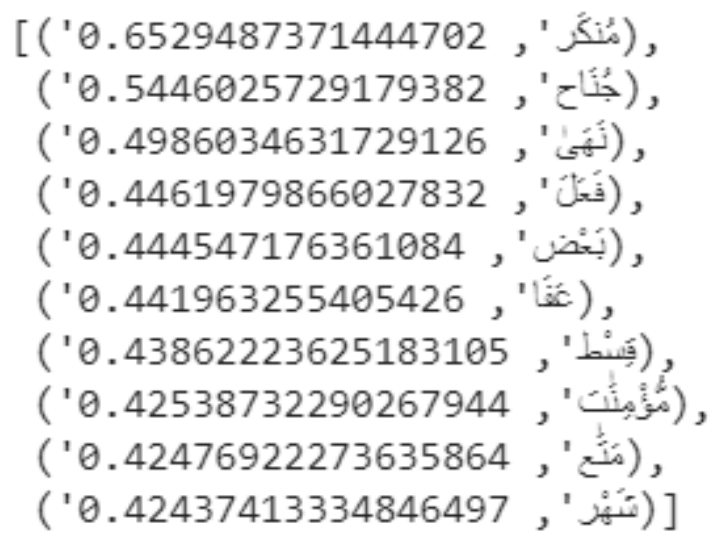

Gambar 5. Contoh Keluaran Sistem

Visualisasi titik yang dilingkari pada Gambar 4 menjelaskan beberapa kata yang memiliki keterkaitan tinggi berdasarkan kedekatan antar vektor yang terbentuk. Kata-kata tersebut dapat dilihat di dalam Tabel 2.

Tabel 2. Perhitungan Precision

\begin{tabular}{|c|c|c|c|}
\hline Nomor Titik & Kata & Keterangan & True Positif \\
\hline 1 & مََْْرُوف & Perbuatan baik & 10 \\
\hline 2 & ذارِ & Keturunan / anak & 9 \\
\hline 3 & عَلِيم & Pengetahuan & 10 \\
\hline
\end{tabular}




\begin{tabular}{|c|c|c|c|}
\hline 4 & مَرْْيَم & Keluarga Maryam & 10 \\
\hline 5 & أَذْنْ & Izin Allah & 10 \\
\hline 6 & عُلْمِ & Pengetahuan & 10 \\
\hline \multicolumn{3}{|c|}{ Precision } & $59 / 60=0.98$ \\
\hline
\end{tabular}

Dari hasil pengujian dapat diketahui nilai precision untuk setiap kata uji. Perhitungan yang dihasilkan dari pengujian terdapat pada Tabel 2 yang menunjukkan angka precision sebesar $98 \%$. Nilai precision yang didapatkan menunjukan tingkat ketepatan antara informasi yang sebenarnya dengan jawaban yang diberikan oleh sistem. Nilai precision pada hasil pengujian sebesar $98 \%$ termasuk dalam kategori sangat akurat.

\section{KESIMPULAN}

Dari hasil penelitian menghasilkan kesimpulan yaitu perhitungan precision menunjukan bahwa sistem yang dibangun memberikan tingkat ketepatan antara informasi yang sebenarnya dengan jawaban yang diberikan oleh sistem sebesar 98\%. Pendekatan distribusional dan perhitungan cosine-similarity dapat menangani permasalahan keterkaitan antar kata dalam AlQur'an berdasarkan dari precison yang didapatkan.

\section{SARAN}

Berikut beberapa saran untuk penelitian tentang keterkaitan kosa kata Al-Qur'an:

1. Penelitian selanjutnya disarankan dapat mencoba menganalisis parameter yang digunakan pada model word2vec.

2. Dan tidak terlepas juga untuk menggunakan metode lain baik yang berbasis vektor atau metode yang tidak memanfaatkan vektor kata.

3. Hasil dari penelitian ini diharapkan dapat memberikan masukan dan menjadi acuan bagi peneliti selanjutnya untuk melakukan penelitian yang sama.

\section{UCAPAN TERIMA KASIH}

Dengan penuh rasa syukur kehadirat Allah SWT dan setelah itu tanpa menghilangkan rasa hormat yang mendalam, saya selaku penyusun dan penulis mengucapkan terima kasih yang sebesar-besarnya kepada Ustaz Nur Muttaqien selaku ahli bahasa Arab Al-Qur'an yang telah membantu penulis untuk menyelesaikan penelitian ini.

\section{DAFTAR PUSTAKA}

[1] A. H. Daud, Z. B. Othman, and N. A. Idris 2018, "Fahaman Syiah dan Keharmonian Agama Islam Di Malaysia: Perspektif Pendekatan Keselamatan," J. Soc. Sci. Humanit., Vol. 13, No. 3, pp. 1-19.

[2] Sahabuddin, M. Q. Shihab, and Sahabuddin 2007, Ensiklopedia Al-Qur'an: Kajian Kosakata, Lentera Hati. 
[3] R. Mihalcea, C. Corley, and C. Strapparava 2006, "Corpus-Based and knowledge-based measures of text semantic similarity," in Proceedings of the National Conference on Artificial Intelligence.

[4] A. W. Z. Nasution, M. A. Bijaksana, and S. Al Farab 2017, "Analisis dan Implementasi Perhitungan Semantics Similarity Pada Ayat Al-Quran Dengan Pendekatan Word Alignment Berdasarkan Support Vector Regression," eProceedings Eng., Vol. 4, No. 2.

[5] M. M. Rani, M. A. Bijaksana, and S. Al Faraby 2017, "Analisis Dan Implementasi Kesamaan Semantik Antar Teks Menggunakan Pendekatan Alignment Dan Vektor Semantik Pada Terjemahan Alquran," eProceedings Eng., Vol. 4, No. 2.

[6] T. Mikolov, K. Chen, G. Corrado, and J. Dean 2013, "Efficient Estimation of Word Representations in Vector Space," arXiv Prepr. arXiv1301.3781.

[7] X. Rong 2014, “word2vec Parameter Learning Explained", arXiv Prepr. arXiv1411.2738.

[8] R. Baeza-Yates, B. Ribeiro-Neto, and Others 1999, Modern Information Retrieval, Vol. 463. ACM press New York.

[9] Aggarwal, Charu C., and ChengXiang Zhai, 2012, eds. Mining Text Dat, Springer Science \& Business Media.

[10] A. Huang 2008, "Similarity Measures for Text Document Clustering," in New Zealand Computer Science Research Student Conference, NZCSRSC 2008 - Proceedings. 